\title{
Epidemiological typing of Yersinia enterocolitica by analysis of restriction fragment length polymorphisms with a cloned ribosomal RNA gene
}

\author{
J. K. ANDERSEN and N. A. SAUNDERS*
}

Institute of Hygiene and Microbiology, Royal Veterinary and Agricultural University, 13 Bulowsvej, DK-1870 Fredericksberg C, Denmark and "Division of Microbiological Reagents and Quality Control, Central Public Health Laboratory, 61 Colindale Avenue, London NW9 5 HT

\begin{abstract}
Summary. Intra-species restriction fragment length polymorphisms (RFLPs) of Yersinia enterocolitica were detected in assays with a cloned DNA fragment from Legionella pneumophila that included the 16S and 23S rRNA genes. By use of this method it was possible to identify different RFLP types within biogroups/serogroups which were indistinguishable by other means. Thus the 37 biogroup IV/serogroup O3 strains isolated worldwide from pig carcasses, pork and human patients, were subdivided into five different RFLP-types. Typing based on RFLP analysis was sensitive and independent of phenotypic characters. The method will be of value for the identification and evaluation of possible reservoirs and routes of infection.
\end{abstract}

\section{Introduction}

Gastroenteritis through infection with Yersinia enterocolitica (yersiniosis) was first recognised in the early $1960 \mathrm{~s}$, and has since been reported with increasing frequency. ${ }^{1-3}$ In Denmark, about 2000 cases of yersiniosis are diagnosed each year. This figure is similar to that for the incidence of gastroenteritis caused by Salmonella and Campylobacter species, the two other most common causes of bacterial gastroenteritis. Only Y. enterocolitica strains of serogroup $\mathrm{O} 3$ are of major importance in Denmark. A few sporadic cases are due to serogroup O9. ${ }^{4}$

Studies on the rate of carriage of $Y$. enterocolitica serogroup $\mathrm{O} 3$ by healthy pigs ${ }^{5-11}$ have revealed frequencies in the range $25-80 \%$ and recent investigations have shown that more than $80 \%$ of Danish herds of pigs are infected. ${ }^{12}$ Therefore, pigs are suspected of being the major reservoir of infection for man. Data from a case-control study strongly support the association between yersiniosis and consumption of raw pork ${ }^{13}$ and porcine and human strains have been found to be indistinguishable by biochemical, serological and phage-typing methods. ${ }^{5,14,15}$ However, direct transmission of $Y$. enterocolitica from pigs to man has not yet been recorded.

Restriction endonuclease digest analysis (REA) of the $Y$. enterocolitica virulence plasmid $^{16}$ has

Received 1 Dec. 1989; accepted 26 Dec. 1989. revealed sequence differences that can be used to distinguish between strains of some serogroups. By this method it was possible to divide strains of serogroup 08 into six plasmid types but among 89 strains of serogroup $\mathrm{O} 3$ of worldwide origin, only one type was observed.

Analysis of the fragment patterns from the total restriction enzyme digestion of chromosomal DNA reveals differences between strains ${ }^{17,18}$ but the complexity of such patterns makes interpretation and comparison of the results obtained on different electrophoretic gels extremely difficult. To avoid the problems associated with complex patterns, several groups of workers have employed probes which hybridise to specific DNA sequences on Southern blots, to detect restriction fragment length polymorphisms (RFLPs) within a limited portion of the chromosomal DNA. This technique (RFLP typing) has been of value in epidemiological studies of various bacterial species. ${ }^{19-21}$

The purpose of this investigation was to use the RFLP method to type $Y$. enterocolitica strains, particularly the human and porcine strains of serogroup $\mathrm{O} 3$, to investigate the possible role of pigs as a reservoir of infection for man.

\section{Materials and methods}

\section{Bacterial strains}

Eighty-five strains of $Y$. enterocolitica were studied. These strains, isolated from man, animals and foods 
worldwide, were of the following biogroups/serogroups: biogroup IV/serogroup O3-37; III/O3-14; other serogroups of biogroup III-2; II/O5, 27-5; II/O9-2; I/ O8-19; and other serogroups of biogroup I-6. Reference strains of other Yersinia spp.- $Y$. frederiksenii NCTC $11470, Y$. intermedia NCTC 11469, Y. kristensenii NCTC 11471, Y. pseudotuberculosis NCTC 10275 and Y. ruckerii NCTC 10476-and representative strains of other enterobacterial species-Salmonella typhimurium, Hafnia alvei, Citrobacter freundii, Klebsiella pneumoniae and Escherichia coli obtained from the culture collection of the National External Quality Assessment Scheme, Colindale-were also examined.

\section{DNA extraction}

Bacterial cells grown for up to $48 \mathrm{~h}$ at $30^{\circ} \mathrm{C}$ on Marmite agar-containing (/L) agar $12 \mathrm{~g}$, Tryptone (Oxoid) $10 \mathrm{~g}$, Marmite $8 \mathrm{~g}$, Acid Hydrolysed Casein (Oxoid) $10 \mathrm{~g}$, sodium glycerophosphate $5 \mathrm{~g}$, sodium lactate $3.5 \mathrm{~g}$, glycerol $5 \mathrm{ml}, \mathrm{MgSO}_{4} .7 \mathrm{H}_{2} \mathrm{O} 0 \cdot 2 \mathrm{~g}, \mathrm{FeSO}_{4} .7 \mathrm{H}_{2} \mathrm{O} 20 \mathrm{mg}$ and $\mathrm{H}_{2} \mathrm{SO}_{4} 2 \mu \mathrm{l}$-were harvested into sterile distilled water and pelleted by centrifugation for $2 \mathrm{~min}$ at $10000 \mathrm{~g}$ in a microcentrifuge. DNA was extracted from bacterial pellets and precipitated with isopropanol as described previously. ${ }^{20,23}$ Contaminating DNAase activity, which was found in the DNA prepared from some strains of Yersinia by this procedure, was inactivated by dissolving the propan-2-ol precipitate in $5 \times$ SSC buffer $(1 \times$ SSC is $0.15 \mathrm{M} \mathrm{NaCl}, 15 \mathrm{~mm}$ sodium citrate, $\mathrm{pH} 7.0$ ) and heating the solution at $80^{\circ} \mathrm{C}$ for $30 \mathrm{~min}$ before recovery of the DNA by ethanol precipitation.

\section{Restriction endonuclease digest analysis}

DNA $(100 \mu \mathrm{g} / \mathrm{ml})$ was digested with the restriction endonucleases EcoRI, HindIII, BamHI, PstI, HaeIII, Sau3A, AvaI, SinI, AluI and NciI 1.2 units/ $\mu$ g of DNA for $2 \mathrm{~h}$ at $37^{\circ} \mathrm{C}$ in the appropriate buffers as recommended by the suppliers of the enzymes. The digests were then chilled on ice and 0.5 volumes of a dye mix containing Ficoll $10 \%$ and bromophenol blue $0.1 \%$ were added; 15 $\mu \mathrm{l}$ samples of these preparations were applied to agarose gels $(1.0 \%)$ in TBE buffer $(0.089 \mathrm{M}$ Tris, $0.089 \mathrm{M}$ boric acid, 0.002 м EDTA) and electrophoresed for either $16 \mathrm{~h}$ at $30 \mathrm{~V}$ or for $5 \mathrm{~h}$ at $100 \mathrm{~V}$. When appropriate, gels were stained with ethidium bromide ( $5 \mathrm{mg} / \mathrm{L}$ ) for $30 \mathrm{~min}$ and examined on a UV transilluminator (UV products).

\section{Southern blotting}

DNA fragments were transferred to nitrocellulose filters by vacuum blotting as described previously. ${ }^{20}$

\section{Preparations of probe DNA}

DNA was purified from $\lambda 142$ bacteriophage particles as described previously. ${ }^{24}$

\section{Labelling and hybridisation of probes}

Purified $\lambda 142$ DNA was labelled with biotin-11-dUTP
(Sigma) by primer extension. Unincorporated dNTPs were not separated from the biotinylated product. Southern blots were hybridised with the biotinylated probe (150 ng) as previously described. ${ }^{24}$ After incubation, the filters were washed at low-stringency in $2 \times \mathrm{SSC}$, SDS $0.1 \%$ at $20^{\circ} \mathrm{C}(2 \times 15 \mathrm{~min}$ and $1 \times 30 \mathrm{~min})$. The filters were developed with the Blu-gene biotin detection reagents (Gibco).

\section{Interpretation of the probed Southern blots}

The molecular size of the restriction fragments observed in each pattern was estimated from a standard curve of relative mobility produced from the known molecular size of the $E c o$ RI and $P$ st I restriction fragments of $\lambda$ phage used as controls. These markers were run in several tracks spaced across the gel. These data and visual examination were used for rapid comparison of the restriction fragment patterns observed, so that strains could be assigned to the appropriate RFLP type.

\section{Results}

\section{Analysis of the restriction endonuclease digests}

Restriction endonuclease fragments of total DNA are shown in fig. 1. It can be seen that strains of the same biogroup/serogroup show very similar fragment patterns and that significant differences are observed in the patterns between biochemically or serologically distinct strains.

\section{Analysis of the probe RFLP-patterns}

Ten restriction endonucleases (EcoRI, HindIII, BamHI, PstI, HaeIII, Sau3A, AvaI, SinI, AluI and $N c i$ ) were assessed for their ability to yield restriction fragments of a suitable number and size after Southern blotting and hybridisation with the probe. Digestion with either $A v a I$ or $N c i$ I resulted in fragment patterns of 5-10 evenly distributed bands, which differed according to the strain employed and which were easily assessed by eye. Therefore, these enzymes were selected for further evaluation.

Examination of the probed $N c i$ I restriction fragments revealed 16 different RFLP types among $84 Y$. enterocolitica strains of various biogroups/ serogroups. The patterns were allocated numbers 1-16 as shown in the table and fig. 2. A blot showing a selection of RFLP types is shown in fig. 3. Strains with the same pattern type were often also of the same biogroup/serogroup. However, strains of the same biogroup/serogroup could often be subdivided according to RFLP type. Thus the 37 strains of biogroup IV/serogroup $\mathrm{O} 3$ and the 19 strains of group I/O8 were of five and four distinct types 


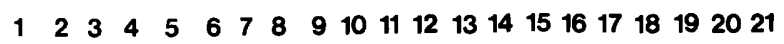

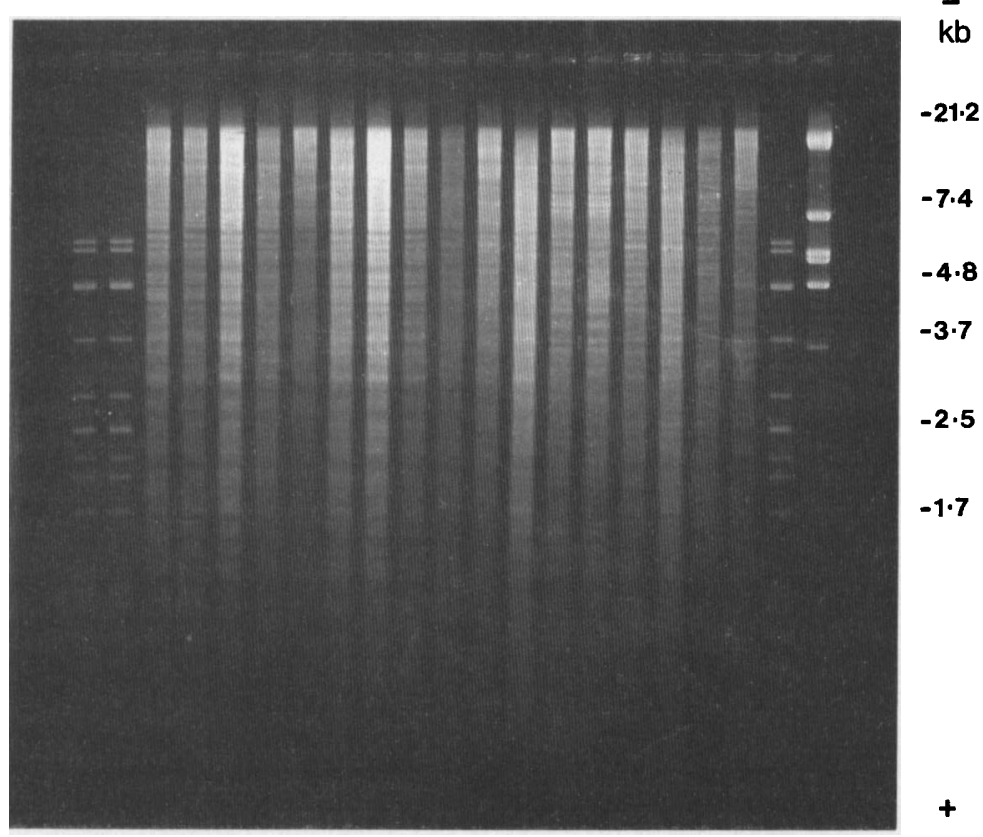

$\overline{\mathrm{kb}}$

$-21 \cdot 2$

$-7.4$

$-4 \cdot 8$

$-3 \cdot 7$

$-2 \cdot 5$

$-1 \cdot 7$

Fig. 1. Analysis of HindIII restriction fragments of total digests of Yersinia DNA. DNA (1 $\mu \mathrm{g}$ ) from Yersinia strains was digested with HindIII and electrophoresed on an agarose gel $(0.8 \%)$ at $1 \mathrm{~V} / \mathrm{cm}$ for $18 \mathrm{~h}$. Tracks 1,2 and 20 , molecular size standards derived by digestion of $\lambda$ phage DNA with PstI and EcoRI; track $21, E c o R I \lambda$ phage digest. $Y$. enterocolitica strains of the following biogroups/serogroups were analysed: tracks 3-9 and 13, biogroup IV/serogroup O3; 10, group III/O3; 11 and 12, biogroup III; 14 and 15 , group I/O8; 16 and 17, II/O5, 27. Tracks 18 and 19 show analyses of $Y$. frederiksenii and $Y$. intermedia respectively.

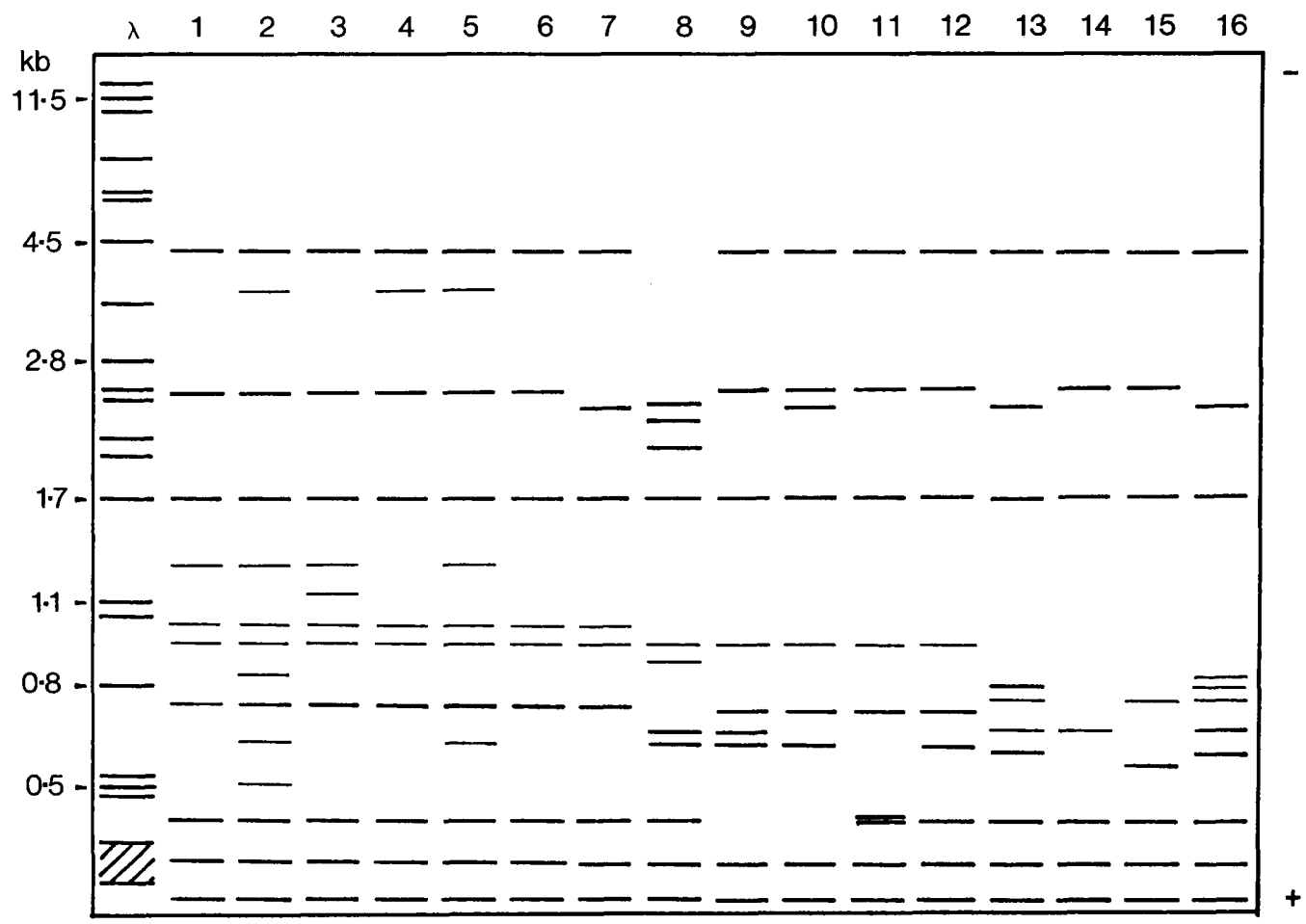

Fig. 2. A diagrammatic representation of the $16 \mathrm{Nci}$-RFLP pattern types of $Y$. enterocolitica. $\lambda$ shows positions of bands from a mixture of Pst and EcoRI $\lambda$ phage digests. 
Table. Summary of the RFLP analyses of isolates by source and country of origin

\begin{tabular}{|c|c|c|c|c|}
\hline \multirow[b]{2}{*}{ Source } & \multirow[b]{2}{*}{ Origin } & \multirow{2}{*}{$\begin{array}{l}\text { Number of } \\
\text { strains }\end{array}$} & \multicolumn{2}{|c|}{$\begin{array}{l}\text { RFLP types with } \\
\text { enzymes }\end{array}$} \\
\hline & & & $N c i \mathrm{I}$ & $A v a \mathrm{I}$ \\
\hline \multicolumn{5}{|c|}{ Biogroup IV/serogroup $\mathrm{O3}$} \\
\hline Pig $^{*}$ & Denmark & 9 & 1 & 1 \\
\hline Pig & Denmark & 1 & 2 & 2 \\
\hline Pig & Denmark & 1 & 2 & 1 \\
\hline Pig & Denmark & 2 & 1 & ND \\
\hline Pig & Denmark & 1 & 2 & ND \\
\hline Man & Denmark & 3 & 1 & 1 \\
\hline Man & Denmark & 2 & 2 & 1 \\
\hline Man & Denmark & 1 & 3 & 1 \\
\hline Man & Denmark & 1 & 1 & ND \\
\hline Man & Denmark & 1 & 2 & ND \\
\hline Pig & Norway & 1 & $\overline{1}$ & 1 \\
\hline Pig & Norway & 2 & 2 & 2 \\
\hline Pig & Norway & 2 & 5 & 1 \\
\hline Pork & Norway & 1 & 1 & 1 \\
\hline Man & Japan & 1 & 2 & 2 \\
\hline Pork & Japan & 1 & 1 & 1 \\
\hline Man & Canada & 1 & 4 & 1 \\
\hline Pork & Canada & 1 & 4 & 1 \\
\hline Man & Spain & 1 & 1 & 1 \\
\hline $\mathrm{NK}^{+}$ & NK & 1 & 1 & 1 \\
\hline Man & UK NCTC 11175 & 1 & 1 & ND \\
\hline Man & UK NCTC 11176 & 1 & 1 & ND \\
\hline Pig & UK NCTC 11177 & 1 & 1 & ND \\
\hline \multicolumn{5}{|c|}{ Biogroup III/serogroup 03 variants } \\
\hline Man & Japan & 2 & 1 & 1 \\
\hline Man & Japan & 1 & 1 & 2 \\
\hline Pork & Japan & 1 & 1 & 1 \\
\hline Pork & Japan & 1 & 4 & 2 \\
\hline Pig & Japan & 6 & 6 & 1 \\
\hline Pig & Japan & 1 & 4 & 1 \\
\hline Pig & Japan & 1 & 6 & 2 \\
\hline Pig & Japan & 1 & ND & 1 \\
\hline \multicolumn{5}{|c|}{ Biogroup III/various serogroups } \\
\hline NK & NK & 1 & 7 & 1 \\
\hline NK & NK & 1 & 8 & 3 \\
\hline \multicolumn{5}{|c|}{ Biogroup I/serogroup 08} \\
\hline Man & USA & 2 & 9 & 4 \\
\hline Man & USA & 3 & 10 & 5 \\
\hline Man & USA & 2 & 10 & 6 \\
\hline Man & USA & 1 & 9 & 4 \\
\hline Man & USA & 1 & 9 & 7 \\
\hline Man & USA & 1 & 11 & 5 \\
\hline Man & Canada & 1 & 9 & 8 \\
\hline Man & Canada & 1 & 9 & 7 \\
\hline Man & Canada & 1 & 9 & 7 \\
\hline Pig & USA & 2 & 9 & 4 \\
\hline Pig & USA & 1 & 12 & 6 \\
\hline Pig & USA & 1 & 9 & ND \\
\hline Man & USA NCTC 10598 & 1 & 9 & ND \\
\hline Man & USA NCTC 10938 & 1 & 9 & ND \\
\hline \multicolumn{5}{|c|}{ Biogroup II/serogroup O5, 27} \\
\hline Man & Canada & 1 & 6 & 9 \\
\hline Pork & Canada & 1 & 6 & 10 \\
\hline
\end{tabular}


Table-Continued.

\begin{tabular}{llccc}
\hline & & & \multicolumn{2}{c}{$\begin{array}{c}\text { RFL types with } \\
\text { enzymes }\end{array}$} \\
\cline { 3 - 6 } Source & Origin & $\begin{array}{c}\text { Number of } \\
\text { strains }\end{array}$ & NciI & AvaI \\
\hline Man & Japan & 1 & 6 & 10 \\
Pig & Japan & 1 & 6 & 11 \\
Dog & Japan & 1 & 6 & 10 \\
Biogroup & II/serogroup O9 & & & \\
Man & Denmark & 1 & 7 & 13 \\
Man & Belgium NCTC 11174 & 1 & 7 & ND \\
Biogroup I/various serogroups & Denmark & 1 & & \\
Pig & Denmark NCTC 10461 & 1 & 13 & 12 \\
Chinchilla & Denm & 1 & 11 & ND \\
Man & USA & 1 & 15 & ND \\
Man & USA & 1 & 16 & ND \\
Man & USA & 1 & 10 & ND \\
Man & USA & & & \\
\hline
\end{tabular}

*'Pig' refers to tonsils, faeces or surfaces of freshly slaughtered pig carcasses. ND, not determined.

NK, not known.

All strains were from the collection of J. K. Andersen.

respectively. In some other cases, no discrimination between strains of the same biogroup/serogroup was observed, e.g. the five group II/O5, 27 strains were all of the same RFLP type as were the group II/O9 strains.
Thirteen of the 14 strains identified as biogroup III variants of serogroup $\mathrm{O} 3$ from pigs, pork and man were of three NciI-RFLP types. These corresponded with the types observed for strains of different biogroups/serogroups, as follows: four

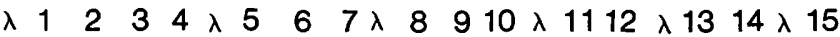

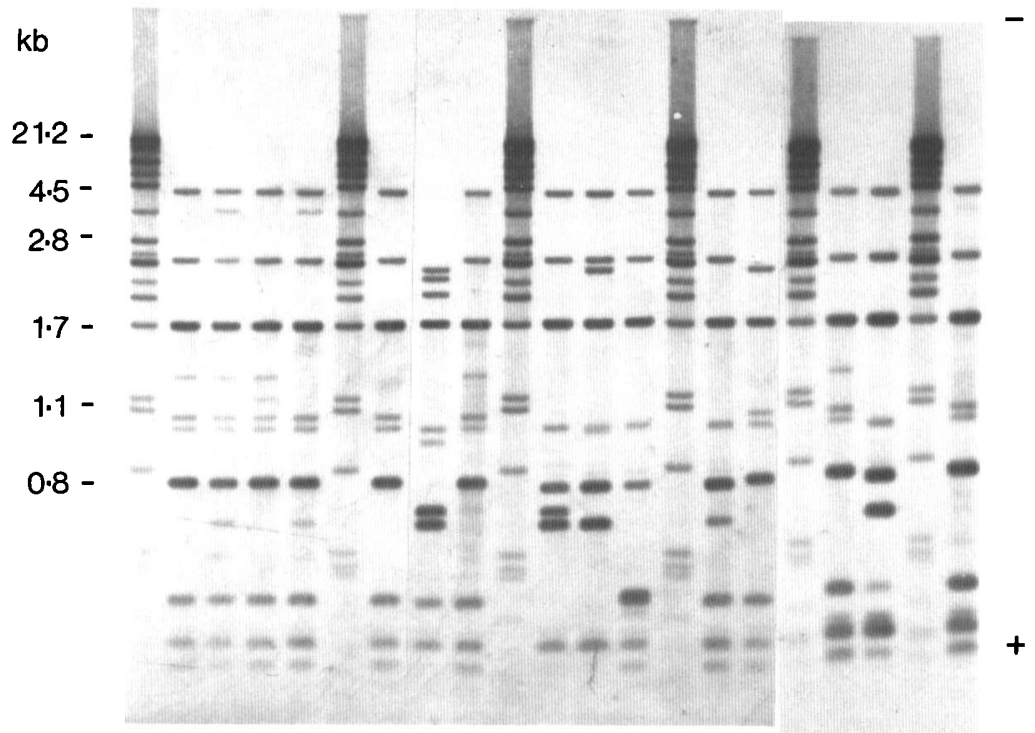

Fig. 3. NciI-restriction fragments from selected $Y$. enterocolitica strains detected with the probe $\lambda 142$. Restriction fragments of DNA (c. $1 \mu \mathrm{g} /$ track) were electrophoresed at $100 \mathrm{~V}$ for $5 \mathrm{~h}$. Tracks marked $\lambda$ show a mixture of EcoRI and PstI digests of $\lambda$ phage DNA. $Y$. enterocolitica strains of the following biogroups/serogroups were analysed: tracks $1-4,7$ and 13 , group IV/O3; 5, group III/O3; 6 , biogroup III ; 8-10 and 14, group I/O8; 11, biogroup I; 12, group II/O9; 15, group II/O5, 27. 
strains were of NciI-RFLP type 1 which was shared by several isolates of group IV/O3; seven strains were of type 6 which was shared by the five group II/O5, 27 strains; and two were of type 4 which was the RFLP type of two of the group IV/O3 strains (the NciI-RFLP type of one of these strains was not determined).

The NciI-RFLP patterns of the other Yersinia spp. and $H$. alvei shared some characteristics with those of the $Y$. enterocolitica strains but were clearly distinct. The restriction fragment patterns of the other enterobacteria examined-S. typhimurium, $K$. pneumoniae, $C$. freundii and $E$. coli shared very few features with those of strains of other Yersinia spp. (fig. 4).

Examination of the probed AvaI restriction fragments revealed 13 different RFLP types among $68 \mathrm{Y}$. enterocolitica strains of various biogroups/ serogroups. The patterns were allocated numbers from 1-13 as shown in the table and fig. 5. Of the 51 serogroup $\mathrm{O} 3$ strains, 43, including the Japanese group III/O3 variants, were of two AvaI-RFLP types. Restriction fragment analysis of 16 of the 19 group I/O8 strains and all of the five group II/O5, 27 strains revealed five and three different patterns respectively.

It is noteworthy that although there was often a

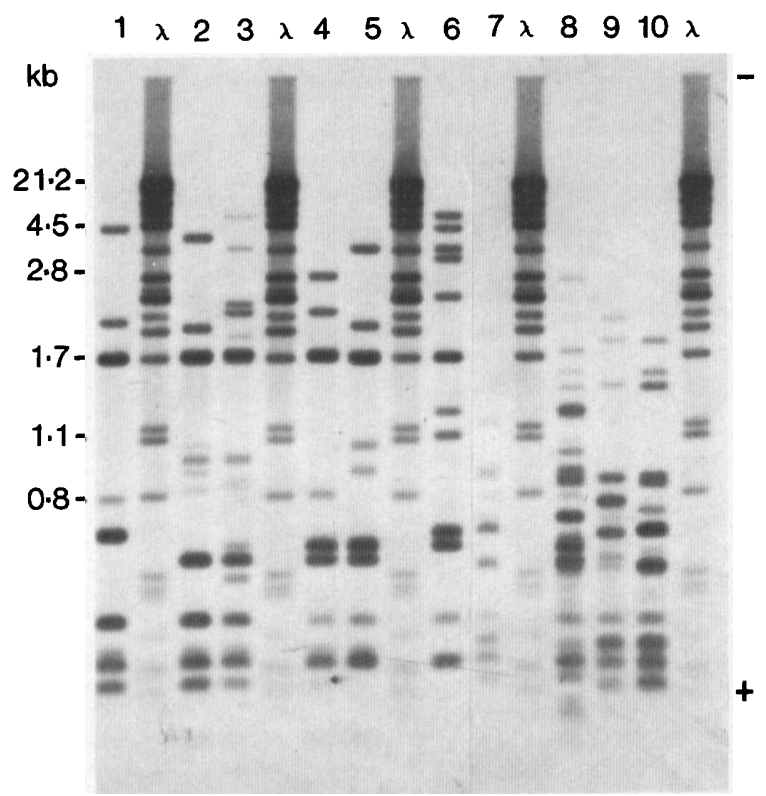

Fig. 4. NciI restriction fragments of DNA from strains of selected Yersinia spp. and other species of enterobacteria. The gel was run and treated as in fig. 3. Track $\lambda$, a mixture of EcoRI and Pst I digests of $\lambda$ phage DNA; track $1, Y$. frederiksenii; $2, Y$. intermedia; 3, Y. kristensenii; 4, Y. pseudotuberculosis; 5, Y. ruckerii; 6, H. alvei; 7, K. pneumoniae $; 8$, E. coli; 9, S. typhimurium; 10, C. freundii. close correlation between the two sets of data, strains of a particular NciI-RFLP type were not always of the same AvaI-RFLP type. Thus typing with both enzymes increased the overall discrimination of the method.

\section{Discussion}

Typing of $Y$. enterocolitica is usually based on biochemical and serological characteristics. ${ }^{14,25-27}$ Phage typing has been used to a limited extent but the discrimination by the available phages is poor ${ }^{28,29}$ Analysis of the $Y$. enterocolitica virulence plasmid by agarose gel electrophoresis of restriction enzyme fragment digests has revealed sequence differences within the plasmid and these can be used to subtype strains of certain serogroups. In a study of 129 strains subtyped by this method Nesbakken et al. ${ }^{16}$ were able to discriminate between serogroup 08 (16 strains, six variants) and serogroup 05, 27 strains (five strains, two variants) but not between strains of serogroup O3 (89 strains) or serogroup 09 (17 strains). However in another study, Pulkkinen et al..$^{30}$ were able to demonstrate the existence of two types of virulence plasmid in 18 serotype $\mathrm{O} 3$ strains of human origin collected in Finland.

The purpose of the present investigation was to assess the value of restriction fragment analysis with an rRNA probe as an additional typing method for $Y$. enterocolitica. Typing on the basis of interstrain RFLPs has the advantage over bio-, sero- and phage-typing that it is independent of environmental factors such as temperature and growth conditions, factors known to affect the phenotype of bacterial cells. ${ }^{31-33}$ Typing systems based on plasmid analysis may also be influenced by environmental conditions since it is known that plasmids may be lost spontaneously as a result of changes in temperature or by exposure to certain chemicals. ${ }^{34-36}$

The interpretation of restriction endonuclease digests of total bacterial DNA obtained with commonly employed enzymes with hexanucleotide sequence recognition sites is extremely difficult. This is because the digest patterns consist of very large numbers of mainly unresolved bands (fig. 1). The complexity of the patterns also makes the comparison of results from different gels difficult. Indeed, patterns on different gels may be compared reliably only if the gel running conditions and other gel parameters can be reproduced very precisely. In practice this is difficult to achieve. Examination of the total restriction fragment banding patterns in this study revealed differences between strains 


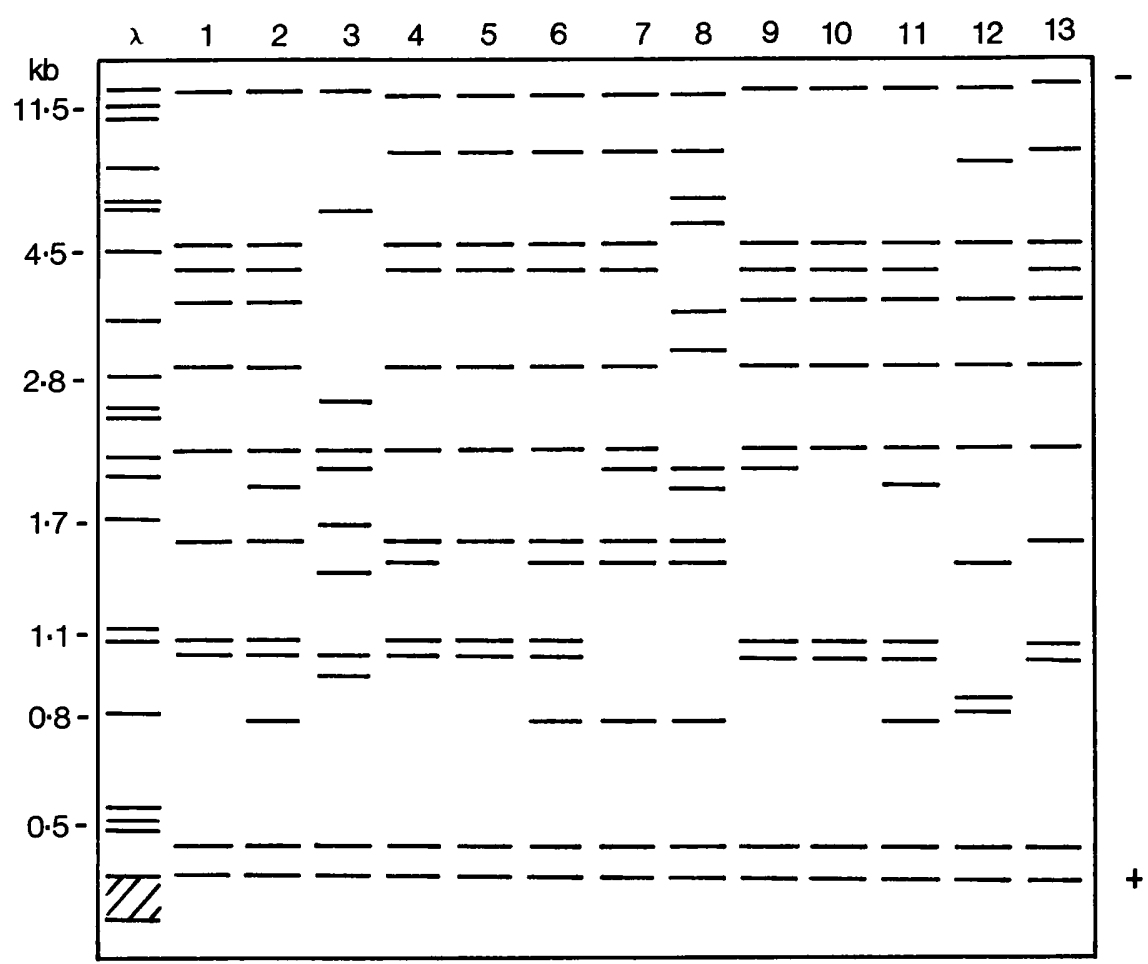

Fig. 5. A diagrammatic representation of the 13 AvaI-RFLP pattern types of $Y$. enterocolitica. $\lambda$ shows position of bands from a mixture of PstI and EcoRI $\lambda$ phage digests.

of different biogroups/serogroups, but we found that the variations within biogroups/serogroups were too subtle for them to be used as reliable markers. For example, restriction endonuclease analysis of the Japanese biogroup III/serogroup O3 variant strains (lane, 10, fig. 1), the group IV/O3 strains (lanes 3-9 and 13, fig. 1) and the group III strains (lanes 11-12, fig. 1) suggests a closer genotypic relationship between the two former groups of strains than between the others but it was not possible to draw firm conclusions based on this data.

A useful solution to the problem of interpretation of total restriction digest patterns is to use a probe to select a small subset of fragments for analysis (RFLP-typing). Many types of probe have been employed for this purpose, including cloned genomic sequences selected solely for their value in RFLP typing, ${ }^{19,37}$ probes which hybridise to chromosomal repeated sequences ${ }^{38}$ and sequences from parts of the chromosome of known function. ${ }^{21,24,39}$ Probes based on the rRNA genes have been employed in several studies involving RFLP analysis for both species identification ${ }^{24}$ and for typing. ${ }^{21}$ Because parts of the rRNA genes are conserved in nature, a probe derived from the rRNA subunits or rRNA genes of one bacterial species will hybridise to the homologous sequences in species belonging to unrelated genera. ${ }^{40}$ The probe employed in this study was a recombinant $\lambda$ phage, labelled with biotinylated nucleotide by primer extension, which carried an rRNA cistron from Legionella pneumophila. This was preferred to the use of end-labelled rRNA subunits from $E$. coli $^{40}$ because the vector sequences of the recombinant phage hybridise to $\lambda$ DNA restriction fragment molecular size markers on the Southern blots to provide a convenient internal standard. The use of rRNA gene probes for typing has the further advantage that several copies of the rRNA operon are present in each chromosome and these may each have a different strain-dependent restriction endonuclease fragmentation pattern resulting in a typing system with good discrimination.

The choice of restriction endonuclease is of considerable importance in RFLP typing since some restriction enzyme sites may be more susceptible to base changes which in turn generate RFLPs. Several restriction enzymes were assessed for their ability to produce RFLPs among strains of $Y$. enterocolitica. Generally, the endonucleases with hexanucleotide sequence recognition sites generated rRNA gene fragments which were highly conserved and few RFLPs could be recognised 
even when strains of different serogroups were analysed. In contrast, when enzymes with penta- or tetranucleotide recognition sites were employed, RFLPs were seen among strains of the same biogroup or serogroup. NciI and $A v a I$, from this latter group of enzymes, were chosen for further evaluation because the patterns produced by them consisted of clear, well-distributed bands.

The RFLP types were usually biogroup/serogroup specific, although in the case of $\mathrm{NciI}$, some strains of different biogroup/serogroup were of the same RFLP type. The use of either AvaI or NciI allowed discrimination between strains of the same biogroup/serogroup. Thus RFLP typing may be useful in work designed to determine the importance of putative sources of infection and routes of transmission of this organism.

There was some evidence of geographical variation in the distribution of RFLP types among the biogroup IV/serogroup $\mathrm{O} 3$ strains. The patterns of the Canadian isolates (NciI-RFLP type 4) and two of the Norwegian isolates (NciI-RFLP type 5) were different from those of any of the other (mostly Danish) strains (table).

The 37 group IV/O3 strains were of $5 \mathrm{NciI}$ and 2 AvaI RFLP types. Differences in the distribution of the patterns between strains isolated from pigs and human patients could not be detected. This is consistent with the hypothesis that pigs are the major reservoir of human yersiniosis. Five of the Danish strains from pigs were found not to contain the virulence plasmid. RFLP typing showed that these strains were indistinguishable from those carrying the plasmid. Clearly, therefore, this typing method can provide useful information even when the virulence plasmid is lost during the isolation and identification of $Y$. enterocolitica strains.

The Japanese group III/O3 variants, ${ }^{41}$ referrea to as biogroup IIIb by Fukushima, ${ }^{42}$ have been considered by Wauters et al. ${ }^{43}$ to be biogroup III variants since biogroup IIIb consists of nonpathogenic environmental strains. RFLP typing of these strains revealed three different patterns among the 13 cleaved with Ncil (NciI-RFLP types 1, 4 and 6). Two of these correspond to the types

\section{REFERENCES}

1. Mollaret HH. L'infection humaine à "Yersinia enterocolitica" en 1970, à la lumière de 642 cas récents. Aspects cliniques et perspectives épidémiologiques. Pathol Biol (Paris) 1971; 19: 189-205.

2. Wauters G, Vandepitte D. Aspects épidémiologues des infections à Yersinia enterocolitica en Belgique. Med Mal Infect 1982; 12: 682-684. observed for group IV/O3 strains and the other was found in group II/O5, 27 strains. Two of the human isolates were of the same RFLP type as one of the isolates from pork, whereas the strains isolated from pigs were of different types (table). This illustrates the potential of this typing method as an epidemiological tool.

RFLP typing of the 19 serogroup 08 and five serogroup O5, 27 strains illustrates how the use of two enzymes may increase the discrimination of the method. Four and five types respectively were revealed by $A v a \mathrm{I}$ and $\mathrm{Nci}$ I digestion of the serogroup O8 strains but when the results were combined seven types were evident. The five serogroup 05 , 27 strains were of NciI-RFLP type 1 and were therefore indistinguishable from most of the group IV/O3 strains examined. However, RFLP analysis with $A v a$ I divided the strains into three types ( $A v a-$ I-RFLP types 9, 10 and 11), types unique to isolates of serogroup O5, 27.

The restriction fragment patterns revealed by analysis of strains belonging to other species of Yersinia and other genera showed marked variations, with few common features between all strains of the various genera examined. Thus, as may be expected, strains shown to be distantly related in serological, biochemical and DNA homology studies shared fewer common bands in RFLP typing than the more closely related isolates.

We have shown that RFLP typing with a probe for rRNA can be used for subtyping various serogroups of $Y$. enterocolitica. The discrimination achieved was good, as judged by the division of groups of related strains indistinguishable by other means. The use of different restriction endonucleases resulted in different subdivisions between groups of strains. The use of additional enzymes for RFLP typing is likely to increase the discrimination of the method even further.

J. K. Andersen was supported by the Danish Agricultural and Veterinary Research Council, grant no. 13-4167. The authors gratefully acknowledge the kind provision of strains by Drs $I$. Bolin, J. Devenish, M. P. Doyle, H. Fukushima, K. Gaarslev, S. Kaneko, C-J. Lian, H. H. Mollaret, T. Nesbakken, T. J. Quan, M. Shayegani, B.Swaminathan, S. Toma and G. Wauters.

3. World Health Organization. Yersiniosis. Report of a WHO meeting, Paris, 1-3 June 1981. (Euro reports and studies no. 60) Copenhagen, Regional Office for Europe, WHO 1983.

4. Anon. Levnedsmiddel- og vandbåren sygdom. EPI-NYT, Statens Serumstitut. 1987: 43.

5. Wauters G. Carriage of Yersinia enterocolitica serotype 3 by pigs as a source of human infection. Contrib Microbiol Immunol 1979; 5 : 249-252. 
6. Pedersen KB. Occurrence of Yersinia enterocolitica in the throat of swine. Contrib Microbiol Immunol 1979; 5: 253-256.

7. Christensen SG. Yersinia enterocolitica in Danish pigs. $J$ Appl Bacteriol 1980; 48: 377-382.

8. Doyle MP, Hugdahl MB, Taylor SL. Isolation of virulent Yersinia enterocolitica from porcine tongues. Appl Environ Microbiol 1981 : 42 : 661-666.

9. Schiemann DA, Fleming CA. Yersinia enterocolitica isolated from throats of swine in eastern and western Canada. Can J Microbiol 1981; 27: 1326-1333.

10. Nesbakken T, Kapperud G. Yersinia enterocolitica and Yersinia enterocolitica-like bacteria in Norwegian slaughter pigs. Int J Food Microbiol 1985; 1 : 301-309.

11. Nesbakken T. Comparison of sampling and isolation procedures for recovery of Yersinia enterocolitica serotype $0: 3$ from the oral cavity of slaughter pigs. Acta Vet Scand 1985; 26: 127-135.

12. Andersen JK. Humanpatogene Yersinia enterocolitica $\mathrm{i}$ danske svinebesaetninger. Thesis. Copenhagen, Denmark, Royal Veterinary and Agricultural University, 1984.

13. Tauxe RV, Vandepitte J, Wauters G et al. Yersinia enterocolitica infections and pork: the missing link. Lancet 1987 ; 1 : 1129-1132.

14. Wauters G. Contribution a l'étude de Yersinia enterocolitica. Thesis. Louvain, Belgium, Vander, 1970.

15. Hurvell B. Zoonotic Yersinia enterocolitica infection: Host range, clinical manifestations, and transmission between animals and man. In: Bottone EJ (ed) Yersinia enterocolitica. Boca Raton, CRC Press. 1981.

16. Nesbakken T, Kapperud G, Sørum H, Dommarsnes K. Structural variability of 40-50 Mdal virulence plasmids from Yersinia enterocolitica. Geographical and ecological distribution of plasmid variants. Acta Pathol Microbiol Immunol Scand [B] 1987; 95 : 167-173.

17. Cleary PP, Kaplan EL, Livdahl C, Skjold S. DNA fingerprints of Streptococcus pyogenes are $\mathrm{M}$ type specific. $J$ Infect Dis 1988 ; 158 : 1317-1323.

18. Penner JL, Hennessy JN, Mills SD, Bradbury WC. Application of serotyping and chromosomal restriction endonuclease digest analysis in investigating a laboratory-acquired case of Campylobacter jejuni enteritis. $J$ Clin Microbiol 1983; 18: 1427-1428.

19. Saunders NA, Kachwalla N, Harrison TG, Taylor AG. Typing of Legionella pneumophila for epidemiological studies using DNA probes. In: Fleurette J, Bornstein N, Marmet D, Surgot M (eds) Colloque Legionella. Collection Fondation Marcel Merieux. 1987: 197-203.

20. Saunders NA. Analysis of restriction fragment length polymorphisms (RFLPs) for epidemiological tracing of bacteria using non-radioactive probes. Focus $1989 ; 11$ : 47-49.

21. Irino K, Grimont F, Casin I, Grimont PAD (The Brazilian Purpuric Fever Study Group). rRNA gene restriction patterns of Haemophilus influenzae biogroup aegyptius strains associated with Brazilian Purpuric Fever. J Clin Microbiol 1988; 26: 1535-1538.

22. Tompkins LS, Troup N, Labigne-Roussel A, Cohen ML. Cloned, random chromosomal sequences as probes to identify Salmonella species. J Infect Dis 1986; 154 : 156162.

23. Pitcher DG, Saunders NA, Owen RJ. Rapid extraction of bacterial genomic DNA with guanidium thiocyanate. Lett Appl Microbiol 1989; 8: 151-156.

24. Saunders NA, Harrison TG, Kachwalla N, Taylor AG.
Identification of species of the genus Legionella using a cloned rRNA gene from Legionella pneumophila. J Gen Microbiol 1988; 134 : 2363-2374.

25. Winblad S. Studies on serological typing of Yersinia enterocolitica. Acta Pathol Microbiol Immunol Scand 1967; Suppl 187: 115.

26. Bercovier $\mathrm{H}$, Brenner DJ, Ursing J, et al. Characterisation of Yersinia enterocolitica sensu stricto. Curr Microbiol $1980 ; 4:$ : 201-206.

27. Wauters G, Kandolo K, Janssens $M$. Revised biogrouping scheme of Yersinia enterocolitica. Contrib Microbiol Immunol 1987; 9: 14-21.

28. Nicolle $\mathrm{P}$, Mollaret $\mathrm{HH}$, Brault J, Nouveaux résultats sur la lysotopie de Yersinia enterocolitica portant surplus de 4000 souches d'origines diverses. Rev Epidemiol Sante Publique 1976; 24 : 479-496.

29. Bercovier H, Brault J, Barre N, Treignier M, Alonso JM, Mollaret HH. Biochemical, serological and phage typing characteristics of 459 Yersinia strains isolated from a terrestrial ecosystem. Curr Microbiol 1978; 1 : 353-357.

30. Pulkkinen L, Granberg I, Granfors K, Toivanen A. Restriction map of the virulence plasmid in Yersinia enterocolitica O:3. Plasmid 1986; 16: 225-227.

31. Bottone EJ. Yersinia enterocolitica: a panoramic view of a charismatic microorganism. CRC Crit Rev Microbiol 1977; 5: 211-241.

32. Pedersen KB. Studies on a haemolytic substance in Yersinia enterocolitica. Acta Pathol Microbiol Scand [B] 1981; 89: 211-214.

33. Cornelis G, Laroche Y, Balligand G, Sory M-P, Wauters G. Yersinia enterocolitica, a primary model for bacterial invasiveness. Rev Infect Dis 1987; 9: 64-87.

34. Hardy K. Bacterial plasmids. Aspects of Microbiology 4. Walton-on-Thames, Surrey, Van Nostrand Reinhold. 1981.

35. Danilevskaya ON, Gragerov AI. Curing of Escherichia coli K 12 plasmids by coumermycin. Mol Gen Genet 1980 ; 178: $233-235$.

36. Portnoy DA, Mosely SL, Falkow S. Characterisation of plasmids and plasmid-associated determinants of Yersinia enterocolitica pathogenesis. Infect Immun 1981 ; 31 : 775-782.

37. Saunders NA, Ridley AM, Taylor AG. Typing of Listeria monocytogenes for epidemiological studies using DNA probes. Acta Microbiol Hung 1989; 36: 205-209.

38. Eisenach KD, Crawford JT, Bates JH. Repetitive DNA sequences as probes for Mycobacterium tuberculosis. $J$ Clin Microbiol 1988; 26 : 2240-2245.

39. Musser JM, Kroll JS, Moxon ER, Selander RK. Clonal population structure of encapsulated Haemophilus influenzae. Infect Immun 1988; 56: 1837-1845.

40. Grimont F, Grimont PAD. Ribosomal ribonucleic acid gene restriction patterns as potential taxonomic tools. Ann Inst Pasteur Microbiol 1986; 137B: 165-175.

41. Kaneko S, Maruyama T. Plasmid-associated properties and biotypes of Yersinia enterocolitica serotype $\mathrm{O}: 3$ strains. Contrib Microbiol Immunol 1987; 9 : 195-200.

42. Fukushima H. Direct isolation of Yersinia enterocolitica and Yersinia pseudotuberculosis from meat. Appl Environ Microbiol 1985; 50: 710-712.

43. Wauters G, Janssens M, Steigerwalt AG, Brenner DJ. Yersinia mollaretii sp. nov. and Yersinia bercovieri sp. nov., formerly called Yersinia enterocolitica biogroups $3 A$ and 3B. Int $J$ Syst Bacteriol 1988; 38 : 424-429. 